Scientific paper

\title{
Vertex Degree Weighted Path Indices
}

\author{
Anton Perdih \\ Faculty of Chemistry and Chemical Technology, University of Ljubljana (retired) Večna pot 113, \\ 1000 Ljubljana, Slovenia \\ * Corresponding author: E-mail: a.perdih@gmail.com
}

Received: 11-09-2015

\begin{abstract}
Vertex degree weighted path indices $\mathrm{P}_{\mathrm{N}}(\mathrm{a}, \mathrm{b}, \ldots)$, for example $\mathrm{P}_{1}(\mathrm{a}, \mathrm{b}), \mathrm{P}_{2}(\mathrm{a}, \mathrm{b}, \mathrm{c}), \mathrm{P}_{3}(\mathrm{a}, \mathrm{b}, \mathrm{c}, \mathrm{d})$, and $\mathrm{P}_{4}(\mathrm{a}, \mathrm{b}, \mathrm{c}, \mathrm{d}, \mathrm{e})$, are good topological indices for some of the physicochemical properties of octanes with $|R|_{\max }$ up to 0.999 . Mutually optimized combinations of them are even better, $R\left(\mathrm{P}_{1} . . \mathrm{P}_{4}\right)$ is in the worst tested case $>0.9$. The best results are obtained in mutually optimized combinations of some of them with some of the elements of the Universal matrix, in the worst tested case $R=0.994$. Some of the vertex degree weighted path one indices give rise to a »regular « sequence of octane isomers of increasing branching.
\end{abstract}

Keywords: Connectivity indices; Octanes; Boiling point; Critical temperature; Critical density; Vapor pressure

\section{Introduction}

Path indices ${ }^{1,2}$ are an eminent group of topological indices and together with the connectivity indices ${ }^{3-6}$ they are frequently used, starting by Wiener ${ }^{7,8}$ and followed by several other authors.

In a private discussion about topological indices, Prof. M. Randić suggested to study the path indices in a similar way as there were studied the indices derived from the Universal matrix $\mathbf{U}(\mathrm{a}, \mathrm{b}, \mathrm{c}),{ }^{9}$ and there should be tested also the combinations of them. The results of this approach are presented below.

\section{Physicochemical Properties of Octanes}

Notations and physicochemical properties (PCP) of octanes are presented elsewhere. ${ }^{10}$ The data for all 18 octane isomers were used, except at the Octane Numbers (BON, MON, RON) and vapor pressure $(\log \mathrm{VP})$, where data for 2,2,3,3-tetramethylbutane are not available, as well as at the surface tension (ST) and refractive index $\left(\mathrm{n}_{\mathrm{D}}\right)$, because 2,2,3,3-tetramethylbutane is not in the liquid state at the room temperature.

\section{Goodness of Topological Indices}

To illustrate the potential goodness of topological indices, the linear correlation between them and the physicochemical properties data is used and the goodness of correlation is expressed as the correlation coefficient $R$ and standard error $S$. Besides them, also the information content ${ }^{10}$ (IC) in the topological index (index combination) is used.

The information content (IC) in the topological index (index combination) in question about the physicochemical property (PCP) of octanes in question is defined as follows: ${ }^{10}$

$$
\begin{aligned}
& I C(\%)=100 \times\left\{1-\left[\sum\left(\mathrm{PCP}_{\exp }-\mathrm{PCP}_{\text {calc }}\right)^{2} /\right.\right. \\
& \left.\left.\sum\left(\mathrm{PCP}_{\exp }-\mathrm{PCP}_{\text {av }}\right)^{2}\right]^{1 / 2}\right\}=100 \times\left\{1-S\left(\mathrm{PCP}_{\exp } ;\right.\right. \\
& \left.\left.\mathrm{PCP}_{\text {calc }}\right) / S\left(\mathrm{PCP}_{\text {exp }} ; \mathrm{PCP}_{\mathrm{av}}\right)\right\}
\end{aligned}
$$

where $\mathrm{PCP}_{\exp }$ means experimental PCP data of octanes, $\mathrm{PCP}_{\text {calc }}$ those calculated from the topological index (index combination) values, and $\mathrm{PCP}_{\mathrm{av}}$ is the average of $\mathrm{PCP}_{\text {exp }}$, whereas $S\left(\mathrm{PCP}_{\text {exp }} ; \mathrm{PCP}_{\text {calc }}\right)$ and $S\left(\mathrm{PCP}_{\text {exp }} ; \mathrm{PCP}_{\text {av }}\right)$ are the respective standard errors.

To the experimental PCP data of octanes, $\mathrm{PCP}_{\text {exp }}$, is ascribed the information content $I C=100 \%$, whereas to the average of $\mathrm{PCP}_{\exp }$ data of octanes, $\mathrm{PCP}_{\mathrm{av}}$, is ascribed the information content $I C=0 \%$ since $\mathrm{PCP}_{\mathrm{av}}$ does not 
contain any information about the contribution of branching in octanes to the value of PCP in question.

The value of $I C$ contributed by particular indices in the index combination is given normalized in such a way that the sum of all particular $I C$ is equal to the value of $I C$ of the topological index combination.

\section{Derivation of Indices}

\section{1. Path Indices}

If we present the path indices ${ }^{1,2}$ in the way used to derive a variety of indices from the Universal matrix $\mathbf{U}(\mathrm{a}$, b, c), ${ }^{9,11}$ we see that they can be presented in the following way:

$$
\begin{aligned}
& \mathrm{p}_{1}=\sum \mathrm{v}_{\mathrm{i}}^{0} \times \mathrm{v}_{\mathrm{j}}^{0} \times 1^{0} \\
& \mathrm{p}_{2}=\sum \mathrm{v}_{\mathrm{i}}^{0} \times \mathrm{v}_{\mathrm{j}}^{0} \times \mathrm{v}_{\mathrm{k}}^{0} \times 2^{0} \\
& \mathrm{p}_{3}=\sum \mathrm{v}_{\mathrm{i}}^{0} \times \mathrm{v}_{\mathrm{j}}^{0} \times \mathrm{v}_{\mathrm{k}}^{0} \times \mathrm{v}_{\mathrm{l}}^{0} \times 3^{0} \\
& \mathrm{p}_{4}=\sum \mathrm{v}_{\mathrm{i}}^{0} \times \mathrm{v}_{\mathrm{j}}^{0} \times \mathrm{v}_{\mathrm{k}}^{0} \times \mathrm{v}_{1}^{0} \times \mathrm{v}_{\mathrm{m}}^{0} \times 4^{0} \\
& \mathrm{p}_{5}=\sum \mathrm{v}_{\mathrm{i}}^{0} \times \mathrm{v}_{\mathrm{j}}^{0} \times \mathrm{v}_{\mathrm{k}}^{0} \times \mathrm{v}_{1}^{0} \times \mathrm{v}_{\mathrm{m}}^{0} \times \mathrm{v}_{\mathrm{n}}{ }^{0} \times 5^{0} \\
& \text { etc. }
\end{aligned}
$$

\section{2. Vertex Degree Weighted Path Indices}

Let us define the vertex degree weighted path of length $\mathrm{N}$ indices $\mathrm{P}_{\mathrm{N}}(\mathrm{a}, \mathrm{b}, \ldots)$ in the following way:

$\mathrm{P}_{\mathrm{N}}(\mathrm{a}, \mathrm{b}, \ldots)=\sum \mathrm{v}_{\mathrm{i}}^{\mathrm{a}} \times \mathrm{v}_{\mathrm{j}}^{\mathrm{b}} \times \ldots \times \mathrm{d}_{\mathrm{N}}^{\mathrm{n}}$, where $\mathrm{v}_{\mathrm{i}}, \mathrm{v}_{\mathrm{j}}$, etc. are the vertex degrees, whereas $d_{N}$ is the distance between the starting and the target vertex in question.

The factor $\mathrm{d}_{\mathrm{N}}^{\mathrm{n}}$ is equal among all vertex degree weighted path indices of the same path length. It is thus a constant, which can be omitted. So the calculation of the vertex degree weighted path indices of the same path length can be simplified into $\mathrm{P}_{\mathrm{N}}(\mathrm{a}, \mathrm{b}, \ldots)=\sum \mathrm{v}_{\mathrm{i}}^{\mathrm{a}} \times \mathrm{v}_{\mathrm{j}}{ }^{\mathrm{b}} \times \ldots$ with $\mathrm{d}_{\mathrm{N}}=$ const. thus:

The vertex degree weighted path indices would be

$$
\begin{aligned}
& \mathrm{P}_{1}(\mathrm{a}, \mathrm{b})=\sum \mathrm{v}_{\mathrm{i}}{ }^{\mathrm{a}} \times \mathrm{v}_{\mathrm{j}}{ }^{\mathrm{b}} \\
& \mathrm{P}_{2}(\mathrm{a}, \mathrm{b}, \mathrm{c})=\sum \mathrm{v}_{\mathrm{i}}{ }^{\mathrm{a}} \times \mathrm{v}_{\mathrm{j}}{ }^{\mathrm{b}} \times \mathrm{v}_{\mathrm{k}}{ }^{\mathrm{c}} \\
& \mathrm{P}_{3}(\mathrm{a}, \mathrm{b}, \mathrm{c}, \mathrm{d})=\sum \mathrm{v}_{\mathrm{i}}^{\mathrm{a}} \times \mathrm{v}_{\mathrm{j}}{ }^{\mathrm{b}} \times \mathrm{v}_{\mathrm{k}}{ }^{\mathrm{c}} \times \mathrm{v}_{1}{ }^{\mathrm{d}} \\
& \mathrm{P}_{4}(\mathrm{a}, \mathrm{b}, \mathrm{c}, \mathrm{d}, \mathrm{e})=\sum \mathrm{v}_{\mathrm{i}}{ }^{\mathrm{a}} \times \mathrm{v}_{\mathrm{j}}{ }^{\mathrm{b}} \times \mathrm{v}_{\mathrm{k}}{ }^{\mathrm{c}} \times \mathrm{v}_{1}{ }^{\mathrm{d}} \times \mathrm{v}_{\mathrm{m}}{ }^{\mathrm{e}} \\
& \text { etc. }
\end{aligned}
$$

The path indices ${ }^{1,2}$ are thus the $\mathrm{P}_{\mathrm{N}}(0,0, \ldots)$ indices. And, all the path indices are in fact the constant distance indices.

For the purpose of keeping the »dimension«, the products shoud be raised to $1 /\left(\mathrm{d}_{\mathrm{N}}+1\right)$ and not to $1 / 2$ only. Writing it explicitly, the vertex degree weighted path indices kept for the »dimension « should be used in the form:

$$
\begin{aligned}
& { }^{\mathrm{d}} \mathrm{P}_{1}(\mathrm{a}, \mathrm{b})=\sum\left(\mathrm{v}_{\mathrm{i}}^{\mathrm{a}} \times \mathrm{v}_{\mathrm{j}}{ }^{\mathrm{b}}\right)^{1 / 2} \\
& { }^{\mathrm{d}} \mathrm{P}_{2}(\mathrm{a}, \mathrm{b}, \mathrm{c})=\sum\left(\mathrm{v}_{\mathrm{i}}^{\mathrm{a}} \times \mathrm{v}_{\mathrm{j}}^{\mathrm{b}} \times \mathrm{v}_{\mathrm{k}}{ }^{\mathrm{c}}\right)^{1 / 3} \\
& { }^{\mathrm{d}} \mathrm{P}_{3}(\mathrm{a}, \mathrm{b}, \mathrm{c}, \mathrm{d})=\sum\left(\mathrm{v}_{\mathrm{i}}^{\mathrm{a}} \times \mathrm{v}_{\mathrm{j}}^{\mathrm{b}} \times \mathrm{v}_{\mathrm{k}}{ }^{\mathrm{c}} \times \mathrm{v}_{1}{ }^{\mathrm{d}}\right)^{1 / 4} \\
& { }^{\mathrm{d}} \mathrm{P}_{4}(\mathrm{a}, \mathrm{b}, \mathrm{c}, \mathrm{d}, \mathrm{e})=\sum\left(\mathrm{v}_{\mathrm{i}}^{\mathrm{a}} \times \mathrm{v}_{\mathrm{j}}^{\mathrm{b}} \times \mathrm{v}_{\mathrm{k}}{ }^{\mathrm{c}} \times \mathrm{v}_{\mathrm{l}}{ }^{\mathrm{d}} \times \mathrm{v}_{\mathrm{m}}{ }^{\mathrm{e}}\right)^{1 / 5} \\
& \text { etc. }
\end{aligned}
$$

However, during the optimization procedure the exponents get automatically corrected for this. It is only to be remembered that the values of optimized exponents are in fact $\mathrm{a}_{\text {opt }}=\mathrm{a} /\left(\mathrm{d}_{\mathrm{N}}+1\right)$, etc.

There could be defined also the starting-and-target vertex weighted path indices. They would be:

$$
\begin{aligned}
& \mathrm{P}_{1 s t}(\mathrm{a}, \mathrm{b})=\mathrm{P}_{1}(\mathrm{a}, \mathrm{b})=\sum\left(\mathrm{v}_{\mathrm{i}}{ }^{\mathrm{a}} \times \mathrm{v}_{\mathrm{j}}{ }^{\mathrm{b}}\right)^{1 / 2} \\
& \mathrm{P}_{2 \mathrm{st}}(\mathrm{a}, \mathrm{b}, \mathrm{c})=\sum\left(\mathrm{v}_{\mathrm{i}}^{\mathrm{a}} \times \mathrm{v}_{\mathrm{j}}{ }^{0} \times \mathrm{v}_{\mathrm{k}}{ }^{\mathrm{c}}\right)^{1 / 3} \\
& \mathrm{P}_{3 \mathrm{st}}(\mathrm{a}, \mathrm{b}, \mathrm{c}, \mathrm{d})=\sum\left(\mathrm{v}_{\mathrm{i}}^{\mathrm{a}} \times \mathrm{v}_{\mathrm{j}}{ }^{0} \times \mathrm{v}_{\mathrm{k}}{ }^{0} \times \mathrm{v}_{\mathrm{l}}{ }^{\mathrm{d}}\right)^{1 / 4} \\
& \mathrm{P}_{4 \mathrm{st}}(\mathrm{a}, \mathrm{b}, \mathrm{c}, \mathrm{d}, \mathrm{e})=\sum\left(\mathrm{v}_{\mathrm{i}}^{\mathrm{a}} \times \mathrm{v}_{\mathrm{j}}{ }^{0} \times \mathrm{v}_{\mathrm{k}}{ }^{0} \times \mathrm{v}_{1}{ }^{0} \times \mathrm{v}_{\mathrm{m}}{ }^{\mathrm{e}}\right)^{1 / 5}
\end{aligned}
$$

If good, they are automatically generated during the optimization procedure, therefore they do not need to be considered separately, except when applying the grid values of exponents, where they may indicate the usefulness of the vertex degree weighted path indices.

The connectivity indices ${ }^{3-6}{ }^{N} \chi^{v}$ are members of the vertex degree weighted path indices, as well:

$$
\begin{aligned}
&{ }^{l} \chi^{v} \equiv \mathrm{P}_{1}(-1 / 2,-1 / 2) \\
&{ }^{2} \chi^{v} \equiv \mathrm{P}_{2}(-1 / 2,-1 / 2,-1 / 2)
\end{aligned}
$$

etc.

If there would be the intention to keep the »dimension « in the connectivity indices, then their form would be as follows:

$$
\begin{aligned}
& { }^{l} \chi^{\ll d "} \equiv \mathrm{P}_{1}(-1 / 2,-1 / 2) \\
& { }^{2} \chi^{\ll d "} \equiv \mathrm{P}_{2}(-1 / 3,-1 / 3,-1 / 3) \\
& \text { etc., and in general, }{ }^{N} \chi^{\ll d "} \equiv \mathrm{P}_{\mathrm{N}}\left(-1 /{ }_{(\mathrm{N}+1)}, \ldots\right) .
\end{aligned}
$$

The vertex degree weighted path length one index can be derived from the right side of the Universal ${ }^{11} \mathrm{U}(\mathrm{a}$, b, c) (Dval $\left.{ }^{12,13}\right)$ matrix by summing the matrix elements containing the factor $1^{\mathrm{c}}$, which is usually not written, cf. Appendix 1. Other starting-and-target vertex degree weighted path indices can be derived from the right side of the Universal ${ }^{11} \mathrm{U}(\mathrm{a}, \mathrm{b}, \mathrm{c})$ (Dval ${ }^{12,13}$ ) matrix by summing the matrix elements containing the factor $2^{\mathrm{c}}, 3^{\mathrm{c}}, 4^{\mathrm{c}}$, etc, respectively.

The Universal matrix ${ }^{11} \mathrm{U}(\mathrm{a}, \mathrm{b}, \mathrm{c})\left(\right.$ Dval $\left.^{12,13}\right)$ presented in Appendix 1, from which the path one indices $\mathrm{P}_{1}(\mathrm{a}$, b) can be derived, is planar, i.e. its dimensionality is equal to 2 . Higher vertex degree weighted path indices, i.e. $\mathrm{P}_{2}(\mathrm{a}$, $\mathrm{b}, \mathrm{c}), \mathrm{P}_{3}(\mathrm{a}, \mathrm{b}, \mathrm{c}, \mathrm{d}), \mathrm{P}_{4}(\mathrm{a}, \mathrm{b}, \mathrm{c}, \mathrm{d}, \mathrm{e})$, etc, can be derived from matrices of higher dimensions. The dimensionality of the general Universal matrix, from which the path $\mathrm{N}$ indices $\mathrm{P}_{\mathrm{N}}(\mathrm{a}, \mathrm{b}, \ldots)=\sum \mathrm{v}_{\mathrm{i}}^{\mathrm{a}} \times \mathrm{v}_{\mathrm{j}}^{\mathrm{b}} \times \ldots \times \mathrm{d}_{\mathrm{N}}^{\mathrm{n}}$ can be derived, is equal to $\mathrm{N}+1$.

\section{3. Usefulness of Vertex Degree Weighted Path Indices}

Whereas the original path one index $\mathrm{p}_{1}$ is degenerated, the $\mathrm{P}_{1}(\mathrm{a}, \mathrm{b})$ indices are in general not. Among octanes only their values for 3M7 and 4M7 are degenerated at all exponent values.

How useful are the indices belonging to these groups we test in relation to the physicochemical properties of octanes. The first step to assess the usefulness of the vertex degree weighted path indices is the goodness of their correlation with the physicochemical properties of octanes. 
To assess where approximately are positioned the maxima in absolute values of correlation coefficient $R$ in the space of exponents $a, b, \ldots$, a multidimensional grid of values of exponents was applied in the way presented earlier ${ }^{9,11}$ and the values of correlation coefficients at those combinations of exponent values were derived. The exponent values $-5,-4,-3,-2,-1,-0.5$, $-0.3,-0.2,-0.1,0,0.1,0.2,0.3,0.5,1,2,3,4$, and 5 were chosen as the grid points in all dimensions of exponents. In several cases, there is indicated by the grid values of exponents more than one local maximum and in such a case more than one is to be tested by the optimization procedure to find the global maximum of the correlation coefficient.

The true maximum of the correlation coefficient can be approached then by exponent optimization using also two-digit and, if necessary, three-digit values of exponents besides the grid values. In present study, the values of exponents were limited to at most three decimals. It has been observed that the first digit in the value of exponent, e.g. in 0.2 , defines in most tested cases the first three decimals of the correlation coefficient. The second digit, e.g. in 0.23 , improves in most tested cases the value of the third to the fifth decimal, depending on how far from the best value of the exponent is its one-digit grid value approximation. The third digit in the exponents $a, b, \ldots$, e.g. in 0.231 , improves the value of the fifth or higher decimal of the correlation coefficient. ${ }^{9}$ For our purpose, in the first step of assessment, three decimals in the correlation coefficient are sufficient, therefore in our first step we use onedigit grid values of exponents. For optimization, five decimals in the value of the correlation coefficient are considered sufficient, therefore only two digits in the value of exponents $a, b, \ldots$ are needed. For the optimization the Simplex method has been used.

To optimize the combination of indices, the approach $\mathrm{TI}_{\text {comb }}=\sum \mathrm{P}_{\mathrm{N}}(\mathrm{a}, \mathrm{b}, \ldots) \times \mathrm{k}_{\mathrm{N}}$ has been used, where $\sum \operatorname{abs}\left(\mathrm{k}_{\mathrm{N}}\right)=1$ and $0<\operatorname{abs}\left(\mathrm{k}_{\mathrm{N}}\right)<1$, and the exponents $\mathrm{a}, \mathrm{b}$, $\ldots$ as well as the smallest $\mathrm{k}_{\mathrm{N}}$ have two significant digits. The exponents $\mathrm{a}, \mathrm{b}, \ldots$ as well as the factors $\mathrm{k}_{\mathrm{N}}$ are mutually optimized to reach the highest $R$ value possible.

\section{Results}

The correlations between the vertex degree weighted path indices and physicochemical properties of octanes have several local maxima in the space of exponents $\mathrm{a}, \mathrm{b}, \ldots$ They can be located using the multidimensional grid of values of exponents. One has to be aware, however, that a global maximum observed using grid values of exponents presented above may not remain a global maximum after optimization of exponent values or after mutual optimization of exponent values and factors $k_{N}$ in $\sum \mathrm{P}_{\mathrm{N}}(\mathrm{a}, \mathrm{b}, \ldots) \times \mathrm{k}_{\mathrm{N}}$ used to optimize the combination of two or more indices.
Vertex degree weighted path one indices $\mathrm{P}_{1}(\mathrm{a}, \mathrm{b})$

The results obtained using vertex degree weighted path one indices $\mathrm{P}_{1}(\mathrm{a}, \mathrm{b})$ using optimized two-digit values of exponents in them and presenting their correlation with physicochemical properties of octanes in form of $|R|_{\max }$, are as follows: $0.996>\omega>\mathrm{BP} / \mathrm{Tc}>\mathrm{Tc} / \mathrm{Pc}>\mathrm{RON}>\mathbf{0 . 9 9 0}$ $>\mathrm{BON}>0.98>\mathrm{Pc}>\mathrm{Tc}^{2} / \mathrm{Pc}>\mathrm{n}_{\mathrm{D}}>\mathrm{C}>\mathbf{0 . 9 7}>\mathrm{MON}>\mathrm{S}$ $>\mathrm{d}>\mathrm{R}^{2}>\Delta \mathrm{Hv}>\mathbf{0 . 9 5}>\mathrm{Vm}>\Delta \mathrm{Hf}^{\circ} \mathrm{g}>\mathrm{MR}>\mathrm{ST}>\mathrm{BP}>$ $0.90>\mathrm{Tc}>\alpha \mathrm{c}>\mathbf{0 . 8 0}>\mathrm{Vc}>\mathrm{B}>\mathrm{dc}>\mathrm{A}>\log \mathrm{VP}>\mathbf{0 . 7 0}$ $>$ Zc $>$ CED $>$ Sol.par. $>\mathbf{0 . 6 0}$.

The $\mathrm{p}_{1} \equiv \mathrm{P}_{1}(0,0)$ index is degenerated.

The $\mathrm{P}_{1}(-1 / 2,-1 / 2)\left(\equiv^{l} \chi^{v}\right)$ index gives rise to $|R|_{\max }$ as follows: $0.95>\Delta \mathrm{Hv}>\mathrm{C}>\mathrm{Tc}^{2} / \mathrm{Pc}>\mathrm{S}>\omega>0.90>\mathrm{RON}$ $>\mathrm{BON}>\Delta \mathrm{Hf}^{\circ} \mathrm{g}>\mathrm{BP}>\mathrm{BP} / \mathrm{Tc}>\mathrm{MON}>\mathbf{0 . 8 0}>\mathrm{R}^{2}>$ $\mathrm{Tc} / \mathrm{Pc}>\log \mathrm{VP}>\mathrm{A}>\mathbf{0 . 7 0}>\mathrm{Zc}>\mathrm{ST}>\mathrm{Pc}>\mathrm{n}_{\mathrm{D}}>\mathrm{d}>\mathrm{Vm}$ $>$ 0.50 $>$ B $>\alpha c>$ MR $>$ Vc $>$ dc $>$ Tc $>$ Sol.par. $>$ CED $>$ 0.08.

Among the vertex degree weighted path one indices a local maximum other than the best grid values one gives rise to a better correlation after optimization of two digit values of exponent in three cases: $\mathrm{C}, \mathrm{ST}$, and A.

Vertex degree weighted path two indices $\mathrm{P}_{2}(\mathrm{a}, \mathrm{b}, \mathrm{c})$

The results obtained using vertex degree weighted path two indices $\mathrm{P}_{2}(\mathrm{a}, \mathrm{b}, \mathrm{c})$ using optimized two-digit values of exponents in them and presenting their correlation with physicochemical properties of octanes as $|R|_{\max }$, are as follows: 0.999 $>\omega>\mathrm{Tc} / \mathrm{Pc}>\mathrm{BP} / \mathrm{Tc}>0.99>\mathrm{RON}>\mathrm{Pc}$ $>0.98>\mathrm{C}>\mathrm{n}_{\mathrm{D}}>\mathrm{BON}>\mathrm{Tc}^{2} / \mathrm{Pc}>\mathrm{d}>\mathbf{0 . 9 7}>\mathrm{Vm}>\mathrm{MON}$ $>\mathrm{S}>0.96>0.95>\Delta \mathrm{Hv}>\mathrm{ST}>\mathrm{R}^{2}>\Delta \mathrm{Hf}^{\circ} \mathrm{g}>\mathrm{BP}>\mathrm{MR}$ $>\mathbf{0 . 9 0}>\mathrm{A}>\mathrm{Vc}>\mathrm{dc}>$ Sol.par. $>\mathrm{CED}>\alpha \mathrm{c}>\mathrm{B}>\mathrm{Tc}>$ $\mathbf{0 . 8 0}>\log \mathrm{VP}>\mathrm{Zc}>\mathbf{0 . 7 0}$.

The $\mathrm{p}_{2} \equiv \mathrm{P}_{2}(0,0,0)$ index gives rise to $|R|_{\max }$ as follows: $0.98>\omega>0.97>\mathrm{C}>\mathrm{S}>\mathbf{0 . 9 5}>\mathrm{Tc}^{2} / \mathrm{Pc}>\mathrm{RON}>$ $\mathrm{BON}>\mathrm{n}_{\mathrm{D}}>\mathrm{BP} / \mathrm{Tc}>\Delta \mathrm{Hv}>\mathbf{0 . 9 0}>\mathrm{MON}>\mathrm{Tc} / \mathrm{Pc}>\mathbf{0 . 8 0}$ $>\mathrm{R}^{2}>\Delta \mathrm{Hf}^{\circ} \mathrm{g}>\mathrm{Pc}>\mathrm{BP}>\mathbf{0 . 7 0}>\mathrm{A}>\log \mathrm{VP}>\mathrm{d}>\mathrm{Vm}>$ $\mathrm{Zc}>\mathrm{MR}>\alpha \mathrm{c}>\mathbf{0 . 5 0}>\mathrm{Vc}>\mathrm{dc}>\mathrm{ST}>\mathrm{B}>\mathrm{CED}>$ Sol.par. $>$ Tc $>\mathbf{0}$.

The connectivity index $\mathrm{P}_{2}(-1 / 2,-1 / 2,-1 / 2)\left(\equiv^{2} \chi^{v}\right)$ gives rise to $|R|_{\max }$ as follows: $0.95>\Delta \mathrm{Hv}>\Delta \mathrm{Hf}^{\circ} \mathrm{g}>\mathbf{0 . 9 0}>\mathrm{BP}$ $>\mathrm{C}>\mathrm{S}>\mathrm{Tc}^{2} / \mathrm{Pc}>\omega>\mathbf{0 . 8 0}>\mathrm{ST}>\mathrm{RON}>\mathrm{BON}>\log \mathrm{PP}$ $>\mathbf{0 . 7 0}>\mathrm{A}>\mathrm{BP} / \mathrm{Tc}>\mathrm{MON}>\mathrm{R}^{2}>\mathrm{Tc} / \mathrm{Pc}>\mathrm{Zc}>\mathrm{B}>\mathbf{0 . 5 0}$ $>\mathrm{n}_{\mathrm{D}}>\mathrm{d}>\mathrm{Vm}>\mathrm{Pc}>\mathrm{Tc}>\alpha \mathrm{c}>\mathrm{Vc}>\mathrm{dc}>$ Sol.par. $>\mathrm{MR}$ $>\mathrm{CED}>\mathbf{0 . 1 0}$.

The connectivity index kept for the »dimension «, $\mathrm{P}_{2}(-1 / 3,-1 / 3,-1 / 3)\left(\equiv^{2} \chi^{« d "}\right)$, gives rise to $|R|_{\max }$ as follows: $0.95>\Delta \mathrm{Hv}>\mathrm{C}>\mathbf{0 . 9 0}>\mathrm{S}>\Delta \mathrm{Hf}^{\circ} \mathrm{g}>\mathrm{Tc}^{2} / \mathrm{Pc}>\omega>\mathrm{BP}$ $>\mathrm{RON}>\mathrm{BON}>\mathbf{0 . 8 0}>\mathrm{BP} / \mathrm{Tc}>\mathrm{MON}>\log \mathrm{VP}>\mathrm{R}^{2}>$ $\mathrm{Tc} / \mathrm{Pc}>\mathrm{A}>\mathbf{0 . 7 0}>\mathrm{ST}>\mathrm{Zc}>\mathrm{n}_{\mathrm{D}}>\mathrm{d}>\mathrm{B}>\mathrm{Vm}>\mathrm{Pc}>$ 0.50 $>\alpha \mathrm{c}>\mathrm{Vc}>\mathrm{dc}>\mathrm{MR}>\mathrm{Tc}>$ Sol.par. $>\mathrm{CED}>$ 0.10.

Among the vertex degree weighted path two indices, a local maximum other than the best grid values one, gives rise to a better correlation after optimization of two digit values of exponent in RON, $\mathrm{Vc}$, and dc, as well as slightly in $\omega, \mathrm{C}, \mathrm{S}, \Delta \mathrm{Hv}$, and $\mathrm{A}$. 
Vertex degree weighted path three indices $\mathrm{P}_{3}(\mathrm{a}, \mathrm{b}, \mathrm{c}, \mathrm{d})$

The results obtained using vertex degree weighted path three indices $\mathrm{P}_{3}(\mathrm{a}, \mathrm{b}, \mathrm{c}, \mathrm{d})$ using optimized two-digit values of exponents in them and presenting their correlation with physicochemical properties of octanes as $|R|_{\max }$, are as follows: 0.991 $>\mathrm{RON}>\mathbf{0 . 9 9}>\mathrm{Tc} / \mathrm{Pc}>\mathrm{Pc}>\mathrm{BP} / \mathrm{Tc}$ $>\mathrm{MON}>\mathrm{BON}>\omega>\mathrm{n}_{\mathrm{D}}>\mathbf{0 . 9 8}>\mathrm{Tc}^{2} / \mathrm{Pc}>\mathrm{d}>\mathbf{0 . 9 7}>\mathrm{Vm}$ $>\mathrm{ST}>\mathrm{C}>\mathrm{R}^{2}>\mathrm{S}>\mathbf{0 . 9 6}>\Delta \mathrm{Hv}>\mathrm{Tc}>\mathrm{BP}>\mathbf{0 . 9 5}>\mathrm{MR}$ $>\Delta \mathrm{Hf}^{\circ} \mathrm{g}>\mathrm{B}>\mathbf{0 . 9 0}>$ Sol.par. $>\mathrm{CED}>\mathrm{Vc}>\alpha \mathrm{c}>\mathrm{dc}>\mathrm{A}$ $>\mathrm{Zc}>\mathbf{0 . 8 0}>\log \mathrm{VP}>\mathbf{0 . 7 0}$.

The $\mathrm{p}_{3} \equiv \mathrm{P}_{3}(0,0,0,0)$ index gives rise to $|R|_{\max }$ as follows: $0.96>\mathrm{Pc}>\mathbf{0 . 9 5}>\mathrm{MR}>\mathbf{0 . 9 0}>\mathrm{Tc} / \mathrm{Pc}>\mathrm{BP} / \mathrm{Tc}>\mathbf{0 . 8 0}$ $>\mathrm{Vc}>\mathrm{Tc}>\mathrm{dc}>\mathrm{Vm}>\omega>\mathbf{0 . 7 0}>\mathrm{d}>\mathrm{n}_{\mathrm{D}}>\mathrm{Tc}^{2} / \mathrm{Pc}>\mathrm{ST}>$ $\mathrm{MON}>\mathrm{S}>\mathrm{RON}>\mathrm{R}^{2}>\mathrm{BON}>\mathrm{C}>\mathrm{CED}>$ Sol.par. $>\mathbf{0 . 5 0}$ $>\alpha \mathrm{c}>\mathrm{B}>\Delta \mathrm{Hv}>\mathrm{Zc}>\mathrm{A}>\mathrm{BP}>\Delta \mathrm{Hf}^{\circ} \mathrm{g}>\log \mathrm{VP}>\mathbf{0}$.

The connectivity index $\mathrm{P}_{3}(-1 / 2,-1 / 2,-1 / 2,-1 / 2)\left(\equiv^{3} \chi^{v}\right)$ gives rise to $|R|_{\max }$ as follows: $0.93>\mathrm{MR}>\mathrm{Pc}>\mathbf{0 . 9 0}>$ $\mathrm{Tc} / \mathrm{Pc}>\mathbf{0 . 8 0}>\mathrm{Tc}>\mathrm{BP} / \mathrm{Tc}>\mathbf{0 . 7 0}>\mathrm{Vm}>\mathrm{Vc}>\mathrm{ST}>\mathrm{dc}>$ $\mathrm{d}>\omega>\mathrm{n}_{\mathrm{D}}>$ Sol.par. $>\mathrm{CED}>\mathrm{S}>\mathrm{Tc}^{2} / \mathrm{Pc}>\mathrm{MON}>\mathrm{RON}$ $>\mathrm{R}^{2}>\mathrm{C}>\mathrm{BON}>\mathbf{0 . 5 0}>\alpha \mathrm{c}>\mathrm{B}>\mathrm{Zc}>\mathrm{BP}>\Delta \mathrm{Hv}>$ $\Delta \mathrm{Hf}^{\circ} \mathrm{g}>\mathrm{A}>\log \mathrm{VP}>\mathbf{0}$.

The connectivity index kept for the »dimension «, $\mathrm{P}_{3}(-1 / 4,-1 / 4,-1 / 4,-1 / 4)\left(\equiv^{3} \chi^{« d \ll}\right)$ gives rise to $|R|_{\max }$ as follows: 0.90 $>$ MR $>$ Pc $>$ Tc $>\mathbf{0 . 8 0}>\mathrm{ST}>\mathrm{Tc} / \mathrm{Pc}>\mathbf{0 . 7 0}>$ $\mathrm{BP} / \mathrm{Tc}>\mathrm{Vm}>\mathrm{Vc}>\mathrm{dc}>\mathrm{d}>$ Sol.par. $>\mathrm{CED}>\omega>\mathrm{n}_{\mathrm{D}}>\mathrm{B}$ $>\mathbf{0 . 5 0}>\mathrm{S}>\mathrm{MON}>\mathrm{RON}>\mathrm{R}^{2}>\mathrm{Tc}^{2} / \mathrm{Pc}>\mathrm{C}>\alpha \mathrm{c}>\mathrm{BON}$ $>\mathrm{BP}>\mathrm{Zc}>\Delta \mathrm{Hf}^{\circ} \mathrm{g}>\log \mathrm{VP}>\Delta \mathrm{Hv}>\mathrm{A}>\mathbf{0}$.

Using best observed grid values of exponents on vertex degree values in vertex degree weighted path three index $\mathrm{P}_{3}(\mathrm{a}, \mathrm{b}, \mathrm{c}, \mathrm{d})$ gives rise to some good correlations, whereas the optimization using two-digit values of exponents gives rise to slight additional improvement of correlation coefficients.

Among the vertex degree weighted path three indices, a local maximum other than the best grid-values one, gives rise to a better correlation after optimization of two digit values of exponents in $\mathrm{B}$, as well as slightly in $\mathrm{n}_{\mathrm{D}}, \mathrm{Vm}, \mathrm{Tc}$, and Zc.

Vertex degree weighted path four indices $\mathrm{P}_{4}(\mathrm{a}, \mathrm{b}, \mathrm{c}, \mathrm{d}, \mathrm{e})$

The results obtained using vertex degree weighted path four indices $\mathrm{P}_{4}(\mathrm{a}, \mathrm{b}, \mathrm{c}, \mathrm{d}, \mathrm{e})$ using optimized two-digit values of exponents in them and presenting their correlation with physicochemical properties of octanes as $|R|_{\max }$, are as follows: $0.996>\mathrm{RON}>\mathrm{Tc} / \mathrm{Pc}>\mathrm{Pc}>\mathrm{MON}>\mathbf{0 . 9 9}$ $>\mathrm{BP} / \mathrm{Tc}>\mathrm{BON}>\omega>\mathbf{0 . 9 8}>\mathrm{Tc}^{2} / \mathrm{Pc}>\mathrm{R}^{2}>\mathbf{0 . 9 7}>\mathrm{ST}>$
Tc $>$ S $>0.96>0.95>\alpha c>$ B $>$ C $>$ MR $>$ Sol.par. $>$ CED $>\mathrm{Vm}>\mathrm{d}>\mathrm{n}_{\mathrm{D}}>\mathbf{0 . 9 0}>\Delta \mathrm{Hv}>\mathrm{Zc}>\mathrm{A}>\mathrm{Vc}>\Delta \mathrm{Hf}^{\circ} \mathrm{g}>\mathrm{dc}$ $>\mathbf{0 . 8 0}>\mathrm{BP}>\log \mathrm{VP}>\mathbf{0 . 7 0}$.

The $\mathrm{p}_{4} \equiv \mathrm{P}_{4}(0,0,0,0,0)$ index gives rise to $|R|_{\max }$ as follows: $0.90>\mathrm{d}>\mathrm{n}_{\mathrm{D}}>\Delta \mathrm{Hv}>\mathbf{0 . 8 0}>\mathrm{Tc}>\mathrm{BP} / \mathrm{Tc}>\mathbf{0 . 7 0}$ $>\omega>\mathrm{A}>\mathrm{CED}>\mathrm{MR}>\mathrm{Tc} / \mathrm{Pc}>\mathrm{Pc}>\mathrm{Tc}^{2} / \mathrm{Pc}>\mathrm{S}>\alpha \mathrm{c}>$ 0.50 $>\mathrm{R}^{2}>\mathrm{Vm}>\mathrm{ST}>$ Sol.par. $>\mathrm{C}>\mathrm{BON}>\mathrm{Vc}>\mathrm{BP}>$ $\log \mathrm{VP}>\mathrm{MON}>\mathrm{B}>\mathrm{Zc}>\mathrm{RON}>\Delta \mathrm{Hf}^{\circ} \mathrm{g}>\mathrm{dc}>\mathbf{0}$.

The connectivity index $\mathrm{P}_{4}(-1 / 2,-1 / 2,-1 / 2,-1 / 2,-1 / 2)\left(\equiv^{4} \chi^{v}\right)$ gives rise to $|R|_{\max }$ as follows: $\mathbf{0 . 8 0}>\mathrm{Vm}>\mathrm{d}>\mathrm{n}_{\mathrm{D}}>\mathbf{0 . 7 0}>\mathrm{S}$ $>\mathrm{BP} / \mathrm{Tc}>\mathrm{Zc}>\mathrm{C}>\omega>\mathrm{Pc}>\mathrm{Tc} / \mathrm{Pc}>\mathrm{CED}>$ Sol.par. $>\mathbf{0 . 5 0}$ $>\mathrm{MR}>\mathrm{Tc}^{2} / \mathrm{Pc}>\Delta \mathrm{Hf}^{\circ} \mathrm{g}>\mathrm{Tc}>\Delta \mathrm{Hv}>\mathrm{RON}>\mathrm{R}^{2}>\mathrm{ST}>\mathrm{B}$ $>\mathrm{BON}>\mathrm{MON}>\mathrm{Vc}>\mathrm{dc}>\mathrm{BP}>\mathrm{A}>\alpha \mathrm{c}>\log \mathrm{VP}>\mathbf{0}$.

The connectivity index kept for the »dimension«, $\mathrm{P}_{4}(-1 / 5,-1 / 5,-1 / 5,-1 / 5,-1 / 5)\left(\equiv^{4} \chi^{« d \ll}\right)$ gives rise to $|R|_{\max }$ as follows: $0.90>\mathrm{Vm}>\mathrm{d}>\mathrm{n}_{\mathrm{D}}>\mathbf{0 . 8 0}>\mathrm{S}>\mathbf{0 . 7 0}>\mathrm{BP} / \mathrm{Tc}>$ Pc $>$ CED $>$ Sol.par. $>\mathrm{C}>\omega>$ Tc $/ \mathrm{Pc}>\mathrm{Zc}>\mathrm{MR}>\mathbf{0 . 5 0}>$ $\mathrm{Tc}>\mathrm{Tc}^{2} / \mathrm{Pc}>\mathrm{ST}>\mathrm{B}>\Delta \mathrm{Hf}^{\circ} \mathrm{g}>\Delta \mathrm{Hv}>\mathrm{RON}>\mathrm{R}^{2}>\mathrm{Vc}>$ $\mathrm{dc}>\mathrm{BON}>\mathrm{MON}>\log \mathrm{VP}>\mathrm{BP}>\alpha \mathrm{c}>\mathrm{A}>\mathbf{0}$.

Also in vertex degree weighted path four index $\mathrm{P}_{4}(\mathrm{a}$, b, c, d, e) the use of best observed grid values of exponents on vertex degree values, compared to those having equal values of exponents, improves the correlations substantially, whereas the optimization using two-digit values of exponents gives rise to slight additional improvement of correlation coefficients.

Among the vertex degree weighted path four indices, a local maximum other than the best grid values one, gives rise to a better correlation after optimization of two digit values of exponents in ST, BON, RON, MON, CED, Sol.par., dc, Vc, Zc, and B, as well as slightly in $\log V P, S$, $\mathrm{R}^{2}, \mathrm{Tc}^{2} / \mathrm{Pc}, \mathrm{Tc} / \mathrm{Pc}, \Delta \mathrm{Hv}, \Delta \mathrm{Hf}^{\circ} \mathrm{g}, \mathrm{BP}, \mathrm{Tc}$, and $\mathrm{C}$.

The best results obtained by using two-digit values of exponents in vertex degree weighted path indices are summarized in Table 1. There can be seen that in ten cases the vertex degree weighted path indices give rise to $|R|_{\max }$ $>0.99$. Six physicochemical properties of octanes are involved in these cases.

\section{1. Synergism Between Path Indices - Mutually Optimized Two-digit Values of Exponents}

To demonstrate the synergism between vertex degree weighted path indices we have chosen seven physi-

Table 1. The best correlations $\left(|R|_{\max }>0.99\right)$ using two-digit values of exponents in vertex degree weighted path indices.

\begin{tabular}{|c|c|c|c|c|c|c|}
\hline$\overline{\mathbf{P C P}}$ & $R$ & $\mathbf{P}_{\mathrm{N}}$ & $R$ & $\mathbf{P}_{\mathrm{N}}$ & $R$ & $\mathbf{P}_{\mathrm{N}}$ \\
\hline$\omega$ & -0.998 & $\mathrm{P}_{2}(\mathrm{a}, \mathrm{b}, \mathrm{c})$ & -0.995 & $\mathrm{P}_{1}(\mathrm{a}, \mathrm{b})$ & & \\
\hline $\mathrm{Tc} / \mathrm{Pc}$ & -0.997 & $\mathrm{P}_{2}(\mathrm{a}, \mathrm{b}, \mathrm{c})$ & -0.995 & $\mathrm{P}_{1}(\mathrm{a}, \mathrm{b})$ & 0.992 & $\mathrm{P}_{4}(\mathrm{a}, \mathrm{b}, \mathrm{c}, \mathrm{d}, \mathrm{e})$ \\
\hline $\mathrm{BP} / \mathrm{Tc}$ & -0.997 & $\mathrm{P}_{2}(\mathrm{a}, \mathrm{b}, \mathrm{c})$ & -0.995 & $\mathrm{P}_{1}(\mathrm{a}, \mathrm{b})$ & & \\
\hline RON & 0.995 & $\mathrm{P}_{4}(\mathrm{a}, \mathrm{b}, \mathrm{c}, \mathrm{d}, \mathrm{e})$ & 0.992 & $\mathrm{P}_{1}(\mathrm{a}, \mathrm{b})$ & -0.990 & $\mathrm{P}_{3}(\mathrm{a}, \mathrm{b}, \mathrm{c}, \mathrm{d})$ \\
\hline MON & -0.992 & $\mathrm{P}_{4}(\mathrm{a}, \mathrm{b}, \mathrm{c}, \mathrm{d}, \mathrm{e})$ & & & & \\
\hline Pc & -0.992 & $\mathrm{P}_{4}(\mathrm{a}, \mathrm{b}, \mathrm{c}, \mathrm{d}, \mathrm{e})$ & & & & \\
\hline
\end{tabular}


cochemical properties of octanes: $\mathrm{MON}, \mathrm{Tc}^{2} / \mathrm{Pc}, \mathrm{n}_{\mathrm{D}}, \mathrm{BP}$, $\mathrm{Tc}$, dc and $\log \mathrm{VP}$, cf. ${ }^{10}$ For the sake of comparison are presented in Table 2 the best results using two-digit values of exponents in the best observed individual vertex degree weighted path index.

The best observed correlations between values of physicochemical properties (PCP) and mutually optimi-

Table 3. The best-observed mutually optimized combinations of vertex degree weighted path indices using two-digit values of exponents and factors $\mathrm{k}_{\mathrm{N}}$ in the case of boiling point of octanes (BP).

\begin{tabular}{lccc}
\hline $\mathbf{P}_{\mathbf{N}}(\mathbf{a}, \mathbf{b}, \ldots)$ & $\mathbf{k}_{\mathbf{N}}$ & $\boldsymbol{R}$ & $\boldsymbol{I C}(\boldsymbol{\%})$ \\
\hline $\mathrm{P}_{1}(-0.40,1.68)$ & -0.0911 & 0.906 & 49.8 \\
$\mathrm{P}_{4}(1.04,-2.3,0.44,-4.1,2.7)$ & 0.4223 & 0.648 & 20.6 \\
$\mathrm{P}_{3}(-2.0,-1.43,-0.82,0.020)$ & 0.4816 & 0.592 & 16.8 \\
$\mathrm{P}_{2}(0.63,-0.71,2.9)$ & -0.0050 & -0.163 & 1.1 \\
$\sum \mathrm{P}_{\mathrm{N}}(\mathrm{a}, \mathrm{b}, \ldots) \times \mathrm{k}_{\mathrm{N}}$ & & 0.993 & 88.3 \\
\hline
\end{tabular}

zed combinations of vertex degree weighted path indices using two-digit values of exponents and factors $\mathrm{k}_{\mathrm{N}}$ in $\sum \mathrm{P}_{\mathrm{N}}(\mathrm{a}, \mathrm{b}, \ldots) \times \mathrm{k}_{\mathrm{N}}$ are illustrated in Table 3 and Figure 1 for the boiling point of octanes (BP). The results for physicochemical properties $\mathrm{MON}, \mathrm{Tc}^{2} / \mathrm{Pc}, \mathrm{n}_{\mathrm{D}}, \mathrm{BP}, \mathrm{Tc}, \mathrm{dc}$ and $\log \mathrm{VP}$ are presented in Appendix 2.

\section{2. Ordering of Structures Using Vertex Degree Weighted Path Indices}

Ordering of structures was introduced by Randić and Wilkins. ${ }^{4}$ They discovered that an ordering based on paths of length two $\left(\mathrm{p}_{2}\right)$ and paths of length three $\left(\mathrm{p}_{3}\right)$ indicates possible trends and behavior for many molecular properties. By considering a grid graph derived by attributing to each isomer coordinates $\left(\mathrm{p}_{2}, \mathrm{p}_{3}\right)$ and connecting points along the coordinate axis, they obtained simple presentations useful for isomer structural interrelations.

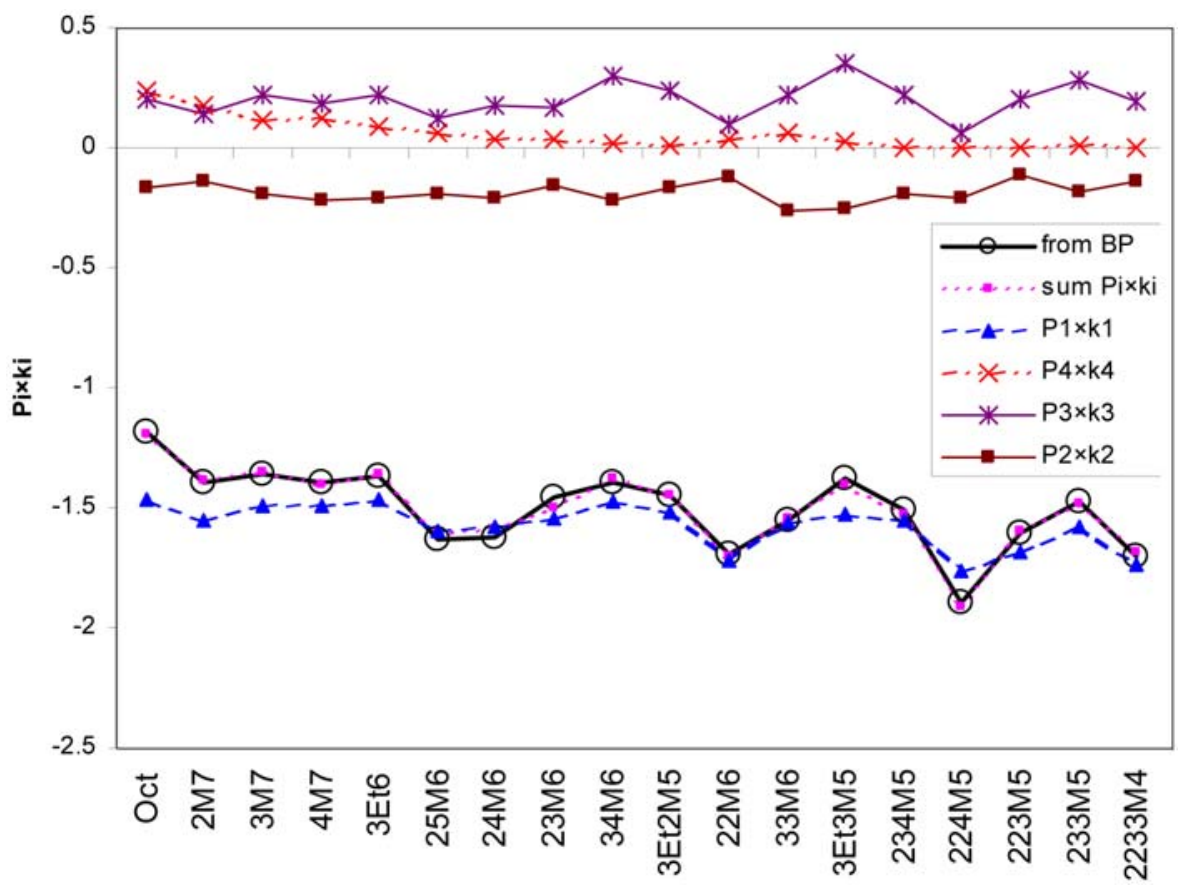

Figure 1. Contribution of particular vertex degree weighted path indices to the optimized combined topological index derived from them in the case of BP of octanes using two-digit values of exponents and factors $\mathrm{k}_{\mathrm{N}}$.

Table 2. The best correlations using the best two-digit values of exponents in individual vertex degree weighted path indices at MON, Tc $2 / \mathrm{Pc}, \mathrm{n}_{\mathrm{D}}$, $\mathrm{BP}, \mathrm{Tc}, \mathrm{dc}$ and $\log \mathrm{VP}$.

\begin{tabular}{llccccccc}
\hline $\mathbf{P C P}$ & $\mathbf{P}_{\mathbf{N}}$ & $\mathbf{a}$ & $\mathbf{b}$ & $\mathbf{c}$ & $\mathbf{d}$ & $\mathbf{e}$ & $\boldsymbol{R}$ & $\boldsymbol{S}$ \\
\hline $\mathrm{MON}$ & $\mathrm{P}_{4}$ & 0.65 & -1.65 & -0.40 & -1.77 & 1.86 & -0.992 & 4.389 \\
$\mathrm{Tc}^{2} / \mathrm{Pc}$ & $\mathrm{P}_{3}$ & -0.26 & -2.3 & -2.3 & 0.135 & & 0.977 & 915 \\
$\mathrm{n}_{\mathrm{D}}$ & $\mathrm{P}_{4}$ & 0.95 & 0.88 & -1.96 & 2.4 & 1.84 & -0.976 & 0.00117 \\
$\mathrm{BP}$ & $\mathrm{P}_{3}$ & -0.98 & -1.33 & -1.67 & -0.197 & & 0.943 & 78.9 \\
$\mathrm{Tc}$ & $\mathrm{P}_{4}$ & 1.09 & 0.97 & -1.30 & 2.4 & 0.165 & -0.962 & 2.093 \\
$\mathrm{dc}$ & $\mathrm{P}_{3}$ & 0.97 & 2.4 & -0.39 & 1.44 & & 0.860 & 6.379 \\
$\operatorname{logVP}$ & $\mathrm{P}_{2}$ & -0.80 & -1.48 & -7.9 & & & 0.760 & 0.004338 \\
\hline
\end{tabular}


A similar procedure can be applied also to the vertex degree weighted path indices and the results are compared to those by Randić and Wilkins. ${ }^{4}$ In order to make such a comparison, one has to recall that $\mathrm{p}_{1}=\mathrm{P}_{1}(0,0), \mathrm{p}_{2}=\mathrm{P}_{2}(0$, $0,0), \mathrm{p}_{3}=\mathrm{P}_{3}(0,0,0,0)$, and $\mathrm{p}_{4}=\mathrm{P}_{4}(0,0,0,0,0)$.

Randić and Wilkins ${ }^{4}$ used in their study only paths of length two, $\mathrm{p}_{2}$, and paths of length three, $\mathrm{p}_{3}$, whereas here are considered the vertex degree weighted path indices $\mathrm{P}_{1}$ through $\mathrm{P}_{4}$, because members of all of them contribute in correlation seeking procedures. The results are presented in Appendix 3.

Within the indices of the same path length, the $\mathrm{P}_{\mathrm{N}}(1$, $1, \ldots)$ vs. $\mathrm{P}_{\mathrm{N}}(0,0 \ldots)$ indices are presented in Figure A3a through A3c. In Appendix 3 is given also the graph having coordinates $\mathrm{p}_{2}$ and $\mathrm{p}_{4}$ [i.e. $\mathrm{P}_{2}(0,0,0)$ and $\mathrm{P}_{4}(0,0,0,0,0)$, Figure A3d.

There is given in Figure A3e also the illustration that the graph of $P_{1}(-1,-1)$ vs. $P_{1}(1,1)$ gives the resolution of most octane isomers. In Figure A3f, on the other hand, is given the demonstration of values of $\mathrm{P}_{2}(3.5,-6.1,3.0)$ and $\mathrm{P}_{4}(0.65,1.06,0.063,0.97,-0.154)$, which contribute together $54.9 \%$ of information about Tc of octanes.

\section{Discussion}

Vertex degree weighted path indices presented here, i.e. $\mathrm{P}_{1}(\mathrm{a}, \mathrm{b}), \mathrm{P}_{2}(\mathrm{a}, \mathrm{b}, \mathrm{c})$, etc., are a generalized form of path indices, which includes besides the original ${ }^{1,2}$ path indices $\mathrm{p}_{1}, \mathrm{p}_{2}$, etc. also the connectivity indices ${ }^{N} \chi^{v} \cdot{ }^{3-6}$ The relations between them are:

$$
\begin{aligned}
& \mathrm{p}_{1} \equiv \mathrm{P}_{1}(0,0) \\
& \mathrm{p}_{2} \equiv \mathrm{P}_{2}(0,0,0) \\
& \text { etc. } \\
& \text { as well as } \\
& { }^{1} \chi^{v} \equiv \mathrm{P}_{1}(-1 / 2,-1 / 2) \\
& { }^{2} \chi^{v} \equiv \mathrm{P}_{2}(-1 / 2,-1 / 2,-1 / 2) \\
& \text { etc. }
\end{aligned}
$$

If there would be the intention to keep in the connectivity indices the »dimension « of the vertex degree, then their form would be as follows:

$$
\begin{aligned}
& { }^{I} \chi^{« d} \equiv \mathrm{P}_{1}(-1 / 2,-1 / 2) \\
& { }^{2} \chi^{« d \ll} \equiv \mathrm{P}_{2}(-1 / 3,-1 / 3,-1 / 3)
\end{aligned}
$$$$
\text { etc., and in general, }{ }^{N} \chi^{\ll d \ll} \equiv \mathrm{P}_{\mathrm{N}}\left(-{ }^{1}{ }_{(\mathrm{N}+1)}, \ldots\right) \text {. }
$$

The path indices and the connectivity indices are in fact the constant distance indices.

The usefulness of vertex degree weighted path indices as well as of vertex degree weighted connectivity indices is presented above, where in the text there are presented the physicochemical properties of octanes sorted by the decreasing absolute value of the correlation coefficient between them and said indices. For comparison there are presented also the values of the correlation coefficients $\left(|R|_{\max }\right)$ using:

- original path index characterized here by the exponents equal to 0 (zero),
- followed by the respective connectivity index characterized by the exponent value of $-1 / 2$,

- as well as by the respective connectivity index kept for the »dimension « of the vertex degree (characterized by the exponent value of $-1 / 2,-1 / 3$, $-1 / 4$, or $-1 / 5$, respectively).

Among the vertex degree weighted path one indices, a local maximum other than the best grid values one, gives rise to a better correlation after optimization of two digit values of exponent in the case of ST, and slightly at C and A.

Among the vertex degree weighted path two indices, such a situation is observed in the case of RON, Vc, and $\mathrm{dc}$, as well as slightly at $\omega, \mathrm{C}, \mathrm{S}, \Delta \mathrm{Hv}$, and A.

Among the vertex degree weighted path three indices, such a situation is observed in the case of $\mathrm{B}$, as well as slightly in $\mathrm{n}_{\mathrm{D}}, \mathrm{Vm}, \mathrm{Tc}$, and $\mathrm{Zc}$.

Among the vertex degree weighted path four indices, such a situation is observed in the case of ST, BON, RON, MON, CED, Sol.par., dc, Vc, Zc, and B, as well as slightly at $\log \mathrm{VP}, \mathrm{S}, \mathrm{R}^{2}, \mathrm{Tc}^{2} / \mathrm{Pc}, \mathrm{Tc} / \mathrm{Pc}, \Delta \mathrm{Hv}, \Delta \mathrm{Hf}^{\circ} \mathrm{g}, \mathrm{BP}$, Tc, and C.

The best cases having $|R|_{\max }>0.99$ are presented in Table 1 . There can be seen that members of all tested vertex degree weighted path indices are involved there, as well as six physicochemical properties of octanes $(\omega$, $\mathrm{Tc} / \mathrm{Pc}, \mathrm{BP} / \mathrm{Tc}, \mathrm{RON}, \mathrm{MON}$, and $\mathrm{Pc}$ ).

If we compare the results using optimized two digit values of exponents to results using grid values of exponents, to results using exponents to keep the »dimension « of the vertex degree, to results using original path indices, to results using original connectivity indices, as well as to results using connectivity indices kept for the »dimension « of the vertex degree, we observe as a general rule that the correlation coefficients are the highest when using optimized two digit values of exponents. They are followed by the correlation coefficients using grid values of exponents. Using tested combinations of equal values of exponents mentioned above gives rise to lower results. For this reason, the use of optimized two digit values of exponents is to be preferred.

There is also the question of what do index the indices $\mathrm{P}_{3}(\mathrm{a}, \mathrm{b}, \mathrm{c}, \mathrm{d})$ and $\mathrm{P}_{4}(\mathrm{a}, \mathrm{b}, \mathrm{c}, \mathrm{d}, \mathrm{e})$ in octanes. The answer to this question can be looked for from two different points of view. One point of view is from the reactivity of the structural elements represented by them. This is relevant for the Octane Number of octanes. Another point of view is from the consequences of the intermolecular attractions and collisions relevant in the case of several other physicochemical properties of octanes.

Let us look first from the point of view of the reactivity of structural elements represented by indices $\mathrm{P}_{3}(\mathrm{a}, \mathrm{b}$, $c, d)$ and $\mathrm{P}_{4}(\mathrm{a}, \mathrm{b}, \mathrm{c}, \mathrm{d}, \mathrm{e})$. The index $\mathrm{P}_{4}(\mathrm{a}, \mathrm{b}, \mathrm{c}, \mathrm{d}, \mathrm{e})$ is derived from structural elements of the general form ... ..., where the degrees of vertices in them are in general different. The formation of hydroperoxides can proceed the fastest when a $\mathrm{CH}_{2}$ group in $\beta$ position is invol- 
ved in it. ${ }^{14,15}$ In a path of length four there are possible from none up to five $\mathrm{CH}_{2}$ groups in one or another $\beta$ position. The real structural features, part of which are these paths of length four, modify the number of $\mathrm{CH}_{2}$ groups in $\beta$ positions and other characteristics influencing the rate of reactions. This is reflected in value of the index $\mathrm{P}_{4}(\mathrm{a}, \mathrm{b}$, $\mathrm{c}, \mathrm{d}, \mathrm{e})$, which gives the best correlation with the Octane Number of octanes. The index $\mathrm{P}_{3}(\mathrm{a}, \mathrm{b}, \mathrm{c}, \mathrm{d})$ represents shorter structural elements with a lower possible number of $\mathrm{CH}_{2}$ groups in $\beta$ position than in the case of $\mathrm{P}_{4}(\mathrm{a}, \mathrm{b}, \mathrm{c}$, d, e).

In the case of other physicochemical properties of octanes, a possible explanation would be that the indices $\mathrm{P}_{3}(\mathrm{a}, \mathrm{b}, \mathrm{c}, \mathrm{d})$ and $\mathrm{P}_{4}(\mathrm{a}, \mathrm{b}, \mathrm{c}, \mathrm{d}, \mathrm{e})$ are i.a. two different measures of the flexibility resp. elasticity of molecules. However, this question deserves a separate study.

\section{1. Synergism Between Path Indices}

The synergism between vertex degree weighted path indices is demonstrated using seven physicochemical properties of octanes: MON, Tc ${ }^{2} / \mathrm{Pc}, \mathrm{n}_{\mathrm{D}}$, BP, Tc, dc and $\log \mathrm{VP}$. The results are presented in Appendix 2, for BP of octanes also in Table 3 and Figure 1, and for the other ones also in Table 5. The results presented in Appendix 2 and Table 4 show that the correlation coefficient of the best observed correlation between $\sum \mathrm{P}_{\mathrm{N}}(\mathrm{a}, \mathrm{b}, \ldots) \times \mathrm{k}_{\mathrm{N}}$ and $\mathrm{MON}, \mathrm{Tc}^{2} / \mathrm{Pc}$, $\mathrm{n}_{\mathrm{D}}, \mathrm{BP}, \mathrm{Tc}$, dc and $\log \mathrm{VP}$, is $|R|\left(\mathrm{P}_{1} . . \mathrm{P}_{4}, \mathrm{PCP}\right)=0.9995>$ $\mathrm{MON}>\mathrm{Tc}^{2} / \mathrm{Pc}>\mathrm{Tc}>\mathrm{BP}>\mathrm{n}_{\mathrm{D}}>0.99>0.94>\log \mathrm{VP}>$ $\mathrm{dc}>0.90$. The »numerical volume « of the combined in-

Table 4. Contribution of vertex degree weighted path indices to the best combination of them.

\begin{tabular}{llc}
\hline $\mathbf{P C P}$ & \multicolumn{1}{c}{$|\boldsymbol{R}|$ and $\boldsymbol{I C}$} & »Num.vol.« \\
\hline $\mathrm{MON}$ & $\mathrm{P}_{4}>\mathrm{P}_{3}>\mathrm{P}_{2}>>>\mathrm{P}_{1}$ & $\mathrm{P}_{1}$ \\
$\mathrm{Tc}^{2} / \mathrm{Pc}$ & $\mathrm{P}_{4}>\mathrm{P}_{1}>\mathrm{P}_{2}>\mathrm{P}_{3}$ & $\mathrm{P}_{1}$ \\
$\mathrm{n}_{\mathrm{D}}$ & $\mathrm{P}_{4}>\mathrm{P}_{3}>\mathrm{P}_{1}>\mathrm{P}_{2}$ & \\
$\mathrm{BP}$ & $\mathrm{P}_{1}>\mathrm{P}_{4}>\mathrm{P}_{3}>>\mathrm{P}_{2}$ & $\mathrm{P}_{1}$ \\
Tc & $\mathrm{P}_{4}>\mathrm{P}_{2}>\mathrm{P}_{3}>\mathrm{P}_{1}$ & $\mathrm{P}_{1}$ \\
dc & $\mathrm{P}_{3}>\mathrm{P}_{1}>\mathrm{P}_{4}>>>\mathrm{P}_{2}$ & $\mathrm{P}_{1}, \mathrm{P}_{2}$ \\
$\operatorname{logVP}$ & $\mathrm{P}_{1}>\mathrm{P}_{2}>\mathrm{P}_{3}>\mathrm{P}_{4}$ & $\mathrm{P}_{2}$ \\
\hline
\end{tabular}

dex is presented mainly by $\mathrm{P}_{1}$, the most of information is contributed by $\mathrm{P}_{4}$ at $\mathrm{MON}, \mathrm{Tc}^{2} / \mathrm{Pc}, \mathrm{n}_{\mathrm{D}}$, and Tc, by $\mathrm{P}_{3}$ at $\mathrm{dc}$, and by $\mathrm{P}_{1}$ at BP and $\log \mathrm{VP}$, Table 4 .

\section{2. Comparison of Results Obtained With Combinations of Path Indices to Those of Combinations of Matrix Elements}

The best results enabling the comparison are given in Table 5 in form of correlation coefficients $R$. There is the question, which situations to compare - equal number of indices in combinations of them or equal number of vertices and distances, which are not constants. In the case of MON we can see the difference between the two approaches. In the case of equal number of indices in the index combination, $R\left(\mathrm{P}_{1} . . \mathrm{P}_{4}\right)>R$ (four $\left.\mathrm{u}_{\mathrm{ij}}\right)$. In the case of equal number of vertices and distances, which are not constants, $R$ (five $\left.\mathrm{u}_{\mathrm{ij}}\right)>R\left(\mathrm{P}_{1} . . \mathrm{P}_{4}\right)$. In the case of $\mathrm{Tc}^{2} / \mathrm{Pc}, R$ $\left(\mathrm{P}_{1} . . \mathrm{P}_{4}\right) \sim R\left(\right.$ five $\left.\mathrm{u}_{\mathrm{ij}}\right)$, in the case of $\mathrm{BP}$ and $\mathrm{Tc}, R\left(\mathrm{P}_{1} . . \mathrm{P}_{4}\right)>$ $R$ (five $\mathrm{u}_{\mathrm{ij}}$ ), in the case of $\mathrm{n}_{\mathrm{D}}, \log \mathrm{VP}$, and dc, $R$ (five $\mathrm{u}_{\mathrm{ij}}$ ) $>R$ $\left(\mathrm{P}_{1} . . \mathrm{P}_{4}\right)$. The situation depends thus on the physicochemical property in question.

\section{3. Combinations of Vertex Degree Weighted Path Indices With Combinations of Elements of the Universal Matrix}

In the worst of the tested cases in Table $5, \mathrm{dc}$, where the best results were $R\left(\operatorname{six~} \mathrm{u}_{\mathrm{ij}}\right)=0.986,{ }^{10}$ and $R\left(\mathrm{P}_{1} . . \mathrm{P}_{4}\right)=$ 0.904 , the mutually optimized combination of the best six elements of the Universal matrix ${ }^{10}\left(\mathrm{u}_{83}, \mathrm{u}_{54}, \mathrm{u}_{76}, \mathrm{u}_{65}, \mathrm{u}_{53}\right.$, and $\left.\mathrm{u}_{32}\right)$, and of $\mathrm{P}_{2}(\mathrm{a}, \mathrm{b}, \mathrm{c})$ gives rise to $R=0.994, S=$ 0.000912 , and $I C=89.3 \%$, Table 6 , which is much better that the result given in Table 5. The vertex degree weighted path two index $\mathrm{P}_{2}(\mathrm{a}, \mathrm{b}, \mathrm{c})$ gives better results than other vertex degree weighted path indices.

In the case of $\log \mathrm{VP}$, the mutually optimized combination of the best six elements of the Universal matrix ${ }^{10}\left(\mathrm{u}_{63}, \mathrm{u}_{72}, \mathrm{u}_{64}, \mathrm{u}_{62}, \mathrm{u}_{75}\right.$, and $\left.\mathrm{u}_{32}\right)$, and of $\mathrm{P}_{2}(\mathrm{a}, \mathrm{b}, \mathrm{c})$ gives rise to $R=0.994, S=0.0196$, and $I C=89.0 \%$, Table 7 , which is again much better that the results given in

Table 5. Goodness of best combinations of vertex degree weighted path indices vs. that of best combinations of elements ${ }^{10}$ of the Universal matrix.

\begin{tabular}{|c|c|c|c|c|}
\hline PCP & $R\left(\mathbf{P}_{1} . . \mathbf{P}_{4}\right)[14]$ & $\boldsymbol{R}\left(\right.$ four $\left.\mathbf{u}_{\mathrm{ij}}\right)$ & $\boldsymbol{R}\left(\right.$ five $\left.\mathbf{u}_{\mathrm{ij}}\right)$ & $R\left(\operatorname{six} u_{i j}\right)$ \\
\hline$\overline{\mathrm{MON}}$ & 0.9993 & 0.996 [12] & 0.9994 [14] & $0.9996[17]$ \\
\hline $\mathrm{Tc}^{2} / \mathrm{Pc}$ & 0.998 & $0.995[12]$ & $0.998[15]$ & 0.999 [17] \\
\hline $\mathrm{BP}$ & 0.993 & $0.984[11]$ & $0.990[14]$ & 0.995 [17] \\
\hline $\mathrm{n}_{\mathrm{D}}$ & 0.992 & $0.989[11]$ & $0.993[14]$ & $0.995[16]$ \\
\hline $\mathrm{Tc}$ & 0.995 & $0.980[11]$ & $0.983[14]$ & $0.986[17]$ \\
\hline $\log V P$ & 0.936 & $0.954[12]$ & $0.973[14]$ & 0.986 [17] \\
\hline $\mathrm{dc}$ & 0.904 & $0.944[11]$ & 0.964 [13] & 0.986 [15] \\
\hline
\end{tabular}

In square brackets: number of vertices and distances between them, contributing to this value since their degrees (values) are not constants (not equal among all isomers). 
Table 6. Best correlation to dc of the combination of six elements of the Universal matrix and of the vertex degree weighted path two index $\mathrm{P}_{2}(\mathrm{a}, \mathrm{b}, \mathrm{c})$ as well as the contributions of individual matrix elements.

\begin{tabular}{lrrr}
\hline $\mathbf{d c}$ & \multicolumn{1}{c}{$\mathbf{k}_{\mathbf{i j}}$} & \multicolumn{1}{c}{$\boldsymbol{R}$} & $\boldsymbol{I C}(\boldsymbol{\%})$ \\
\hline $\mathrm{u}_{83}\left(1^{\mathrm{a}},-2.7,-0.25\right)$ & -0.3581 & 0.737 & 28.0 \\
$\mathrm{u}_{53}\left(-0.126,-0.39,2^{\mathrm{c}}\right)$ & 0.3168 & -0.556 & 14.6 \\
$\mathrm{u}_{54}(-3.0,-2.6,-1.20)$ & 0.1851 & 0.550 & 14.2 \\
$\mathrm{u}_{76}(0.68,2.7,0.90)$ & -0.0052 & 0.548 & 14.1 \\
$\mathrm{u}_{65}(-0.055,-3.0,-0.37)$ & -0.0649 & -0.547 & 14.0 \\
$\mathrm{u}_{32}\left(0.94,-2.3,1^{\mathrm{c}}\right)$ & 0.0588 & 0.286 & 3.6 \\
$\mathrm{P}_{2}(-0.67,-0.60,0.87)$ & -0.0111 & -0.130 & 0.7 \\
Sum of them & & 0.994 & 89.3 \\
\hline
\end{tabular}

Table 5. Also in this case, the vertex degree weighted path two index $\mathrm{P}_{2}(\mathrm{a}, \mathrm{b}, \mathrm{c})$ gives rise to better results than other vertex degree weighted path indices.

Extrapolation to $2233 \mathrm{M} 4$ presents the value of $\log \mathrm{VP}$ $=3.45$.

Table 7. Best correlation to $\log \mathrm{VP}$ of the combination of six elements of the Universal matrix and of the vertex degree weighted path two index $\mathrm{P}_{2}(\mathrm{a}, \mathrm{b}, \mathrm{c})$ as well as the contributions of individual matrix elements.

\begin{tabular}{lrrr}
\hline $\mathbf{u}_{\mathbf{i j}}$ & \multicolumn{1}{c}{$\mathbf{k}_{\mathbf{i j}}$} & \multicolumn{1}{c}{$\boldsymbol{R}$} & $\boldsymbol{I C}(\boldsymbol{\%})$ \\
\hline $\mathrm{u}_{63}(-,-5.3,1.06)$ & 0.3361 & 0.588 & 29.3 \\
$\mathrm{u}_{72}(-0.29,-2.1,-2.0)$ & 0.4984 & 0.571 & 27.4 \\
$\mathrm{u}_{64}(-1.19,1.90,-1.18)$ & -0.0047 & -0.367 & 10.7 \\
$\mathrm{P}_{2}(-0.44,-1.97,-1.30)$ & 0.0439 & 0.299 & 7.0 \\
$\mathrm{u}_{62}(3.0,0.96,-2.2)$ & -0.0022 & -0.280 & 6.2 \\
$\mathrm{u}_{75}(0.047,0.30,0.36)$ & -0.0849 & -0.247 & 4.8 \\
$\mathrm{u}_{32}\left(2.3,-5.7,1^{\mathrm{c}}\right)$ & 0.0298 & -0.217 & 3.6 \\
Sum of them & & 0.994 & 89.0 \\
\hline
\end{tabular}

\section{4. Ordering of Structures}

Randić and Wilkins ${ }^{4}$ introduced and discussed the significance of the results of ordering of alkane isomers based on paths of length two $\left(\mathrm{p}_{2}\right)$ and paths of length three $\left(\mathrm{p}_{3}\right)$ as well as their conceptual value.

Whereas the path of length one index, $\mathrm{p}_{1}$, is totally degenerated, its value being among octanes equal to 7 , other $\mathrm{p}_{\mathrm{N}}$ indices are degenerated to some extent only. The degeneration of $p_{2}$ and $p_{3}$, as well as their integer values enabled Randić and Wilkins ${ }^{4}$ to form rectangular grid graphs in form of coordinate systems similar to Mendeleev's periodic system of elements.

Similar forms are obtained also using the $\mathrm{P}_{\mathrm{N}}(1,1, \ldots)$ vs. $\mathrm{P}_{\mathrm{N}}(0,0 \ldots)$ indices within the indices of the same path length, cf. Figures A3a through A3c in Appendix 3.

In Figure $A 3 a$, the index $P_{2}(0,0,0)$ distributes the octane isomers according to the number of branches. It separates also those having only tertiary carbons from those having quaternary carbons grouping 234M5 among those having two branches on a quaternary carbon. The index $\mathrm{P}_{2}(1,1,1)$, on the other hand, separates the centrally substituted isomers from the peripherally substituted ones. 3Et2M5 is not separated from 34M6.

In Figure A3b, the index $\mathrm{P}_{3}(0,0,0,0)$ separates the centrally substituted isomers from the peripherally substituted ones, whereas the index $\mathrm{P}_{3}(1,1,1,1)$ separates the groups of isomers according to the number of branches.

In Figure $\mathrm{A} 3 \mathrm{c}$ the separation is not that straightforward. The indices $\mathrm{P}_{4}(0,0,0,0,0)$ and $\mathrm{P}_{4}(1,1,1,1,1)$ separate the octane isomers by some other not yet resolved criteria.

There is given also the graph having coordinates $\mathrm{p}_{2}$ and $\mathrm{p}_{4}$ [i.e. $\mathrm{P}_{2}(0,0,0)$ and $\mathrm{P}_{4}(0,0,0,0,0)$ ], Figure $\mathrm{A} 3 \mathrm{~d}$, which did not serve well to the purpose of Randić and Wilkins. ${ }^{4}$

While $\mathrm{p}_{1}=\mathrm{P}_{1}(0,0)$ is not useful due to its total degeneration, the graph of $\mathrm{P}_{1}(-1,-1)$ vs. $\mathrm{P}_{1}(1,1)$, Figure $\mathrm{A} 3 \mathrm{e}$, gives the resolution of most octane isomers. There is evident the separation according to the number of branches, the position of branches, the separation between branches, and type of branches (Et or M). Although the shape of the grid is not rectangular, the separations are clearly visible with exception of two pairs of isomers, of $3 \mathrm{M} 7$ and $4 \mathrm{M} 7$ as well as $34 \mathrm{M} 6$ and 3Et2M5, which are not separated.

In mutually optimized combinations of the vertex degree weighted path indices, the appearence of the distribution of octane isomers may be quite complicated. This is demonstrated in Figure A3f in Appendix 3 for the values of $\mathrm{P}_{2}(3.5,-6.1,3.0)$ and $\mathrm{P}_{4}(0.65,1.06,0.063,0.97$, -0.154 ), which contribute together $54.9 \%$ of information about Tc of octanes.

Bonchev and Trinajstić ${ }^{16}$ formulated several general rules for branching based on Wiener ${ }^{7}$ index that were improved later. ${ }^{17}$ Randic ${ }^{18}$ reminded that branching was in fact attempted to be defined using few topological indices, either the Wiener index ${ }^{7}$ or the largest eigenvalue of the adjacency matrix ${ }^{19,20}$ and he provided the largest eigenvalue of the path matrix as a new basis for the definition of branching. ${ }^{18}$ Randić and Wilkins ${ }^{4}$ followed with the ordering of structures based on path indices. Later ${ }^{21}$ were presented »regular «, in part intuitively derived sequences of octane isomers of increasing branching, one of them being Oct $<2 \mathrm{M} 7<3 \mathrm{M} 7<4 \mathrm{M} 7<3 \mathrm{Et} 6<25 \mathrm{M} 6<24 \mathrm{M} 6<$ $23 \mathrm{M} 6<34 \mathrm{M} 6<3$ Et2M5 < 22M6 < 33M6 < 3Et3M5 < 234M5 < 224M5 < 223M5 < 233M5 < 2233M4, as well as the indices derived from a simplified version of the Universal matrix giving rise to such »regular « sequences of octane isomers. Such a »regular « sequence is observed among some of the indices ${ }^{10,11,22} \mathrm{~V}(\mathrm{a}, \mathrm{b}, \mathrm{c}) \equiv \mathrm{V}_{\mathrm{wm}}(\mathrm{a}, \mathrm{b}, \mathrm{c})$ and $V_{L}(a, b, c)$. The graphs presenting the values of exponents at $\mathrm{V}_{\mathrm{L}}(\mathrm{a}, \mathrm{b}, \mathrm{c}), \mathrm{V}_{\mathrm{wm}}(\mathrm{a}, \mathrm{b}, \mathrm{c})$ and $\mathrm{P}_{1}(\mathrm{a}, \mathrm{b})$ giving rise to such $a »$ regular « sequence of octane isomers are presented in Appendix 4. The relations between the exponents a, $b$, 
and $\mathrm{c}$ in $\mathrm{V}_{\mathrm{L}}(\mathrm{a}, \mathrm{b}, \mathrm{c})$, and $\mathrm{V}_{\mathrm{wm}}(\mathrm{a}, \mathrm{b}, \mathrm{c})$ giving rise to the »regular « sequence of octane isomers presented above are quite complex, see Appendix 4, Figure A4a through A4e. Among the path indices, such a »regular « sequence of octane isomers is observed only at $\mathrm{P}_{1}(\mathrm{a}, \mathrm{b})$. The graph presenting the values of exponents at $\mathrm{P}_{1}(\mathrm{a}, \mathrm{b})$ giving rise to a »regular « sequence of octane isomers is presented in Appendix 4, Figure A4f, within the a, b plane marked by dots. In Appendix 3, Figure A3g, is presented such a sequence based on $\mathrm{P}_{1}(-0.05,-1)$ and $\mathrm{P}_{1}(0.5,0.2)$.

The best observed two digit values of exponents in $\mathrm{P}_{1}(\mathrm{a}, \mathrm{b})$ itself as well as in the mutually optimized exponents $a, b$ and factor $k_{N}$ in the combination of path one through path four indices, Appendix 2, in correlation with MON, $\mathrm{Tc}^{2} / \mathrm{Pc}, \mathrm{BP}, \mathrm{n}_{\mathrm{D}}, \mathrm{Tc}, \mathrm{dc}$, and $\log \mathrm{VP}$ are outside the plane marked by dots in Appendix 4, Figure A4f. Thus, as a rule, the values of exponents giving rise to a »regular « sequence of octane isomers do not give rise to good correlations with tested physicochemical properties of octanes.

Path indices $\mathrm{P}_{2}(\mathrm{a}, \mathrm{b}, \mathrm{c}), \mathrm{P}_{3}(\mathrm{a}, \mathrm{b}, \mathrm{c}, \mathrm{d})$, and $\mathrm{P}_{4}(\mathrm{a}, \mathrm{b}, \mathrm{c}$, $\mathrm{d}, \mathrm{e})$ do not give rise to such a »regular « sequence of octane isomers. Their usefulness in fitting correlation procedures obviously derives from this fact, where they contribute information about physicochemical properties of octanes, which is not contained in the »regular « sequences of octane isomers.

\section{Conclusions}

The vertex degree weighted path of length $\mathrm{N}$ indices $\mathrm{P}_{\mathrm{N}}(\mathrm{a}, \mathrm{b}, \ldots)$ are defined in the following way: $\mathrm{P}_{\mathrm{N}}(\mathrm{a}, \mathrm{b}$, $\ldots)=\sum v_{i}^{a} \times v_{j}^{b} \times \ldots \times d_{N}^{n}$, where $v_{i}, v_{j}$, etc. are the vertex degrees, whereas $d_{N}$ is the distance between the starting and the target vertex in question. These vertex degree weighted path indices were found to be promising topological indices for several physicochemical properties of octanes with $|R|_{\max }$ up to 0.999 . The mutually optimized combinations of them are even better than individual vertex degree weighted path indices with the worst tested case $R$ $\left(\mathrm{P}_{1} . . \mathrm{P}_{4}\right)>0.9$. The best results are obtained in mutually optimized combinations of some of them with some of the elements of the Universal matrix, in the worst tested case $R=0.994$.

\section{References}

1. J. R. Platt, J. Chem. Phys. 1947, 15, 419-420. http://dx.doi.org/10.1063/1.1746554

2. M. Randić, J. Chem. Educ. 1992, 69, 713-718. http://dx.doi.org/10.1021/ed069p713

3. M. Randić, J. Am. Chem. Soc. 1975, 97, 6609-6615. http://dx.doi.org/10.1021/ja00856a001

4. M. Randić, C. L. Wilkins, J. Phys. Chem. 1979, 83, 15251540. http://dx.doi.org/10.1021/j100474a032

5. L. B. Kier, L. H. Hall, J. Pharm. Sci. 1976, 65, 1806-1809. http://dx.doi.org/10.1002/jps.2600651228

6. L. B. Kier, L. H. Hall, Molecular Connectivity in StructureActivity Analysis, Willey, New York, 1986.

7. H. Wiener, J. Am. Chem. Soc. 1947, 69, 17-20. http://dx.doi.org/10.1021/ja01193a005

8. H. Wiener, J. Am. Chem. Soc. 1947, 69, 2636-2638. http://dx.doi.org/10.1021/ja01203a022

9. A. Perdih, F. Perdih, Acta Chim. Slov. 2006, 53, 180-190.

10. A. Perdih, Acta Chim. Slov. 2015, 62, 879-888. DOI: 10.17344/acsi.2015.1607.

11. A. Perdih, B. Perdih, Acta Chim. Slov. 2004, 51, 598-609.

12. O. Ivanciuc, Rev. Roum. Chim. 1999, 44, 519-528.

13. O. Ivanciuc, Rev. Roum. Chim. 2000, 45, 587-596.

14. C. Chevalier, J. Warnatz, H Melenk, Ber. Bunsenges. Phys. Chem. 1990, 94, 1362-1367.

http://dx.doi.org/10.1002/bbpc.199000033

15. A. Perdih, F. Perdih, Acta Chim. Slov. 2006, 53, 306-315.

16. D. Bonchev, N. Trinajstić, J. Chem. Phys. 1977, 67, 45174533. http://dx.doi.org/10.1063/1.434593

17. D. Bonchev, J. Molec. Struct. (Theochem), 1995, 336, 137-156. http://dx.doi.org/10.1016/0166-1280(94)04081-3

18. M. Randić, Acta Chim. Slov. 1997, 44, 57-77.

19. L. Lovasz, J. Pelikan, Period Math Hung. 1973, 3, 175-182. http://dx.doi.org/10.1007/BF02018473

20. D. M. Cvetković, I. Gutman, Croat. Chem. Acta, 1977, 49, 115-121.

21. A. Perdih, Indian J. Chem, 2003, 42A, 1246-1257.

22. A. Perdih, Acta Chim. Slov. 2015, 62, 385-388. http://dx.doi.org/10.17344/acsi.2014.1164

\section{Povzetek}

Indeksi poti z uteženimi vrednostmi njihovih točk $\mathrm{P}_{\mathrm{N}}(\mathrm{a}, \mathrm{b}, \ldots)$, na primer $\mathrm{P}_{1}(\mathrm{a}, \mathrm{b}), \mathrm{P}_{2}(\mathrm{a}, \mathrm{b}, \mathrm{c}), \mathrm{P}_{3}(\mathrm{a}, \mathrm{b}, \mathrm{c}, \mathrm{d})$ in $\mathrm{P}_{4}(\mathrm{a}, \mathrm{b}, \mathrm{c}$, $\mathrm{d}, \mathrm{e}$ ), so dobri topološki indeksi za nekatere fizikalno-kemijske lastnosti oktanov $\mathrm{z}|R|_{\max }$ do 0.999 . Njihove medsebojno optimirane kombinacije so še precej boljše, $R\left(\mathrm{P}_{1} . . \mathrm{P}_{4}\right)$ je v najslabšem preizkušenem primeru $>0,9$. Najboljše rezultate dobimo, če jih optimiramo z nekaterimi elementi Univerzalne matrike, kar da v najslabšem preizkušenem primeru $R=$ 0,994. Nekateri indeksi poti dolžine ena $\mathrm{z}$ uteženimi vrednostmi njihovih točk razvrstijo izomere oktanov v $\gg$ pravilno« zaporedje po naraščajoči razvejanosti. 